\title{
PROTECTING PHILIPPINE OVERSEAS CONTRACT WORKERS
}

\author{
DAVID M. FORMAN $\dagger$
}

Sa lunting pangarap nagmula ang lahat, Binaligtad ang bulsa't nilikon ang danas.

Sa nagtangkarang gusali't karatula'y sumilong,

Itlog ng tagak ang ibig matunton.

Amo kong Intsik kunwa'y mabait,

Ginagahasa ako kung gabing tahimik-

Pagkat ang ipinanagako'y ceramics at jade,

Inialay ko ang takot sa altar ng AIDS.

Nalaman ko ngayong hindi siya tapat, Kahit dibdib nami'y madalas maglapat.

Makapal pa sa buhok ang duming nakalugayy,

Ang garing na isip ay hindi tiwasay.

Kulang pa sa sukat ang balakang

Ang insusulit kong pagdaramdam-ako'y pakinggan:

Nagmamadali kasi ako sa pagyaman, Buntis ako ngayon, walang matuluyan.

$$
\text { -Elynia S. Mabanglo }{ }^{1}
$$

It all started in a dream:

I searched my pockets and gathered experiences.

I took refuge in tall signs and buildings.

Hoping to find the heron's nest.

My Chinese master pretends to be kind-

Rapes me on stark and silent nights.

Because he promises me ceramics and jade,

$I$ offered my fears on the altar of AIDS.

Now I know he isn't true,

Although our breasts often construe.

Thicker than my hair is my shame,

The ivory in my mind is always to blame.

Listen, please, the length of my pains is longer

Than my hips are wider.

Since I am in a hurry to get rich, I am now pregnant and have no place to go.

-Elynia S. Mabanglo ${ }^{2}$

$\dagger$ Judicial Law Clerk, Hawai'i Supreme Court Associate Justice Robert G. Klein; J.D. 1993, University of Hawai'i, William S. Richardson School of Law; B.A. 1988, Harvard College. I would like to thank the late Dr. Elias T. Ramos, former Director of the Pacific \& Asian Management Institute, for his guidance during the initial research stages of the article, and my aunt, Madeline Vargas, who sent valuable information and reference material from the Philippines and discussed the article with Philippine Labor Secretary Nieves Confesor.

1. Elynia S. Mabanglo,... Mula sa Hong Kong [Pinay's Letter from Hong Kong], in MGa Liham ni Pinay 41 (1990).

2. Id. (author's translation). 
The exploitation of overseas workers takes place in various forms and in numerous countries. ${ }^{3}$ The media in the United States has exposed claims of exploitation by foreign workers through reports of abuses perpetrated by Kuwaiti employers. ${ }^{4}$ Although a U.S. congresswoman called the rapes, beatings, and nonpayment of wages in Kuwait "human rights violations and crimes against women," the problems of migrant labor are not always accorded such prominent attention. Despite the widespread nature of this problem, few, if any, truly effective means are available to protect migrant workers from abuse. Some potential for worker protection exists in the enforcement of contemporary legal standards, as well as through ratification of obligations detailed in international treaties. However, practical and political considerations make realization of this potential unlikely. Meanwhile, more women fall prey to situations like those described in the poem above. These women are continuously subjected to otherwise avoidable abuse, as they sacrifice themselves in the individual/national quest for "the heron's nest."

This article reviews the existing regulatory scheme governing Philippine overseas contract workers. Part I introduces the

3. See, e.g., Maria Luz Y. Baguioro, Filipina "Hepatitis" Victim Was Murdered, Officials Say; Philippine Investigators Want an Inquiry, NIKKEI WKLY, Oct. 26, 1991, at 2 (The Philippines Department of Foreign Affairs regularly receives reports about Filipina domestic workers in Saudi Arabia, Singapore, and Germany who are either raped or mistreated by their employers.); Jeremy Clift, Philippines Imposes Ban on Dancers Going to Japan, ReUTER LiBR. ReP., Nov. 20, 1991 ("Nearly a million Filipinos get jobs abroad, working as skilled labour in Saudi Arabia and the Gulf, as merchant seamen, and as housemaids in Singapore and Hong Kong, sending money home to supplement meager family incomes ... [t] here are frequent reports of women being abused."); Daniel Martin, Taiwan's Gloss Fades for Imported Labor, E. Express, Aug. 5, 1994, at 9 ("Exploitation, abuse and usury are forcing foreign workers to go on the run as their dreams turn to nightmares."); Senator Asks Security for P.I. Workers, Honolulu StaR-Bulletin, Sept. 21,1994 , at A10 (reporting that a Filipina was raped, sodomized, and beaten daily for three weeks while working on the island of Rota in the Northern Marianas; the allegation was discovered following a U.S. Senate Committee hearing on September 15, 1994, regarding charges of widespread abuses against migrant workers in U.S. territory).

4. Jack Kelley, Kuwait Rape Reports to be Probed, USA TodaY, Mar. 3, 1992, at A4 (reporting that Rep. Pat Schroeder took a trip to Kuwait to investigate claims of abuse and maltreatment of Filipina household workers); Feminists Protest Kuwait Abuse of Women, Honolulu Star-Bulletin, Apr. 1, 1992, at A8 [hereinafter Kuwait Abuse].

5. Kuwait Abuse, supra note 4, at A8. The Philippine embassy in Kuwait was quoted in the Arab Times as saying that the 1988 ban on overseas employment of Filipina maids "has been ineffective" and that "hundreds of Filipinas lured by promises of attractive pay, weekly leave the country as tourists and head for the Gulf to work as housemaids." Nasra M. Shah et al., Asian Women Workers in Kuwait, 25 InT'L Migration Rev. 464, 484 (1991).

6. The quoted phrase refers to a Philippine metaphor that is much like the "pot of gold at the end of the rainbow" adage in U.S. culture. Additionally, the reference to a national quest reflects the fact that "[ $t$ ]he [Philippine] economy is boosted and balance of payments gap closed through remittances of about $\$ 1.5$ billion a year from Filipinos working abroad mainly in the Middle East, Hong Kong and throughout South East Asia...." Kevin Rafferty, Philippines: the Economic and Business Report, 1993/94 AsIA \& PACIFIC Rev. 212, 216 [hereinafter AsIA \& PACIFIC Rev. 1993/94]. 
Philippines' labor export policy in light of the country's social, economic, cultural, and political characteristics. The problems associated with labor exploitation are then illustrated in Part II. ${ }^{7}$ This part provides specific accounts of abuse, governmental responses to exploitation (e.g., regulation of illegal recruitment), and the shortcomings of state involvement in overseas employment. Part III explores various mechanisms available to protect overseas workers from the Philippines (1) within the Philippines itself, (2) between the exporting and importing governments, (3) in the host country, and (4) through non-governmental organizations. Part IV evaluates the existing regulatory scheme and the continuing viability of the Philippines' labor export policy. Finally, Part V considers the potential for improvement of Filipino worker protection abroad.

\section{BACKGROUND}

From 1974 to 1985, the Philippine government's policy on the export of labor espoused two objectives: (1) promotion of overseas employment opportunities for Filipino workers; and (2) alleviation of the nation's balance of payment deficit by generating foreign exchange. ${ }^{8}$ On May 21, 1985, the Philippine government promulgated "New Rules and Regulations on Overseas Employment" that foretold a minor change in its policy focus. ${ }^{9}$ These new rules state that:

It shall be the policy of the Administration to:

(a) promote and develop overseas employment opportunities in cooperation with relevant government institutions and the private sector;

(b) establish an environment conducive to the continued operations of legitimate and responsible private agencies; and

(c) afford protection to Filipino workers and their families, promote their investments and safeguard their welfare. ${ }^{10}$

To explain the rationale for overseas labor migration from the Philippines, and the government's motivation for making significant policy

7. Although this Article emphasizes the victimization of Filipina women, the reader should recognize that men and women from many other countries also suffer an alarming range of abuse in their overseas employment.

8. Dean Tiburcio Alegado, The Political Economy of International Labor Migration from the Philippines 149, 176 (Ph.D. dissertation, University of Hawai'i (Manoa), on file with author). See also Bruce A. Lindquist, Systems and Social Processes of International Movement from the Philippines (1991) (unpublished M.A. thesis, University of Hawai'i (Manoa), on file with author).

9. Labor Code of the Philippines 588-620 (Jose N. Nolendo ed., 1989) [hereinafter LABOR CODE.].

10. Id. at 588 (citing Rule 1: General Statement of Policy) (emphasis added). Upon her appointment as Secretary of the Department of Labor under newly-elected President Fidel Ramos, Nieves Confesor vowed to continue pursuing these three goals. Dante Reyes, The Lady at the DOLE, Phil. Panorama, July 26, 1992, at 30. 
changes over the years, this article begins by presenting some characteristics of the Philippines that are essential to an understanding of its labor exportation economy.

\section{A. Philippine Demographics}

As of July 1992, the Philippine population was $67,114,060$ with an estimated growth rate of $2 \% .{ }^{11}$ The portion of its labor force considered to be highly educated (i.e., with $90 \%$ literacy for both men and women above fifteen years of age $)^{12}$ was estimated at approximately 24.12 million in $1989 . .^{13}$ The country's labor market is characterized by the following factors: (a) a rapidly increasing labor force; (b) a heavy concentration in agriculture; (c) a small and stagnant industrial and manufacturing sector; (d) a concentration of employment in small sized firms; (e) a large pool of unemployed persons; and (f) a serious underemployment problem. ${ }^{14}$ In 1991, the Asian Development Bank complained about the erosion of human capital resources in the Philippines. In doing so, it noted that,

[a]lthough unemployment has declined in the Aquino years from 11.1 per cent in 1985 to 8.3 per cent in 1990 , according to official figures, the fastest growing employment has been contract workers going abroad. They increased by 34 per cent in the five years to 1990. The second largest growth sector has been services, and employment and manufacturing has actually dropped from 10.9 per cent to 10.4 per cent. ${ }^{15}$

\section{B. Economic Considerations}

Following an economic contraction in 1984 and 1985, the Philippine economy maintained positive growth before slowing significantly again in $1990 .{ }^{16}$ However, by 1991 the economy was back on track,

11. Central Intelligence Agency, The World Factbook 1992, 274 (1992) [hereinafter WORLD FACtBOOK 1992].

12. In 1986, only the United States, Canada, New Zealand, Japan, Greece, and East Germany had a higher proportion of college-educated workers in their populations. EliAS T. RA. mos, Dualistic Unionism and Industrial Relations 23 (1990).

13. WORLD FACTBOOK 1992, supra note 11, at 274.

14. RAMOS, supra note 12 , at 30 . The term "underemployment" refers to skilled workers who take jobs for which they are over-qualified.

15. Kevin Rafferty, Philippines: The Economic and Business Report, 1991/92 Asia \& PA. Cific Rev. 192, 199 [hereinafter Asia \& Pacific Rev. 1991/92] (emphasis added).

16. World FactBook 1992, supra note 11, at 275. See also Asia \& PACific Rev. 1991/92, supra note 15, at 197 ("The Hong Kong brokerage house Peregrine reported that 'Natural disasters, drought, an earthquake and a typhoon-coinciding with Saddam Hussain's abortive attempt to annexe [sic] Kuwait and force up world oil prices, brought economic havoc to an already beleaguered Philippines in the second half of 1990.' ").

The gap between the rich and poor also appears to be growing in the Philippines. For example, the 1990 estimation that three million slum dwellers live in the capital indicates that prosper- 
with stable exchange rates, falling interest rates, and a government surplus. Nonetheless, exports remained a black spot on the economic picture. ${ }^{17}$ As of late 1994, the Philippine economy was still recovering from the 1991 eruption of Mount Pinatubo, which wreaked havoc on a wide range of businesses and devastated the country as a whole. The key economic indicators, based primarily on 1991 data, follow: ${ }^{18}$

Gross National Product (GNP)
GNP per capita
Real growth in GNP
Inflation
Unemployment
Budget

$\$ 47$ billion
$\$ 720$
$0.1 \%$ (1991 estimate)
$17.6 \%$ (1991 estimate)
$10 \%$
$\$ 8.4$ billion. $^{19}$

In 1992, the Philippine economy was affected by two important political changes: (1) Fidel Ramos was elected president on May 11, 1992 , with a narrow plurality of $23.6 \%$ of the vote; and (2) the country said a final farewell to U.S. soldiers who had been based in the country for more than ninety years. ${ }^{20}$ Moreover, in an effort to generate debt relief, as well as $\$ 2.3$ billion in new funds, in February 1992 international institutions and commercial banks rescheduled $\$ 5.3$ billion of the country's debts (totalling $\$ 29$ billion). ${ }^{21}$ Although the Philippine economy barely improved in 1992, while the Gross Domestic Product declined by $0.04 \%$, the Gross National Product went up by $0.62 \%$ because of higher remittances from Filipinos working abroad. ${ }^{22}$ Nonetheless, the Philippines remains among the poorest countries in terms of income, ranking below Lesotho, Mauritania, and Sri Lanka, and barely above Zambia, Togo, and the Central African Republic. ${ }^{23}$

In 1993, the Philippines began negotiations with the International Monetary Fund (IMF) for funding of a growth-oriented program geared towards achieving double-digit economic growth by $1998 .{ }^{24}$ Although IMF officials were wary because of a prior balance of payment crisis following a period of rapid economic growth in the Philippines, in late 1992 World Bank officials noted that "the business sector

ity has not been spread equally, and that further problems will present themselves in the future. Id. at 199.

17. Asia \& PaCific Rev. 1991/92, supra note 15, at 197.

18. WORLD FACTBOOK 1992, supra note 11, at 275.

19. The budget includes $\$ 9,36$ billion in expenditures, of which $\$ 1.8$ billion constitutes capital expenditures. Id.

20. Asia \& Pacific Rev. 1993/94, supra note 6, at 212.

21. Id. at 214 .

22. Id.

23. Id

24. Id. at 215 . 
is . . . in a healthy state[,] ... [b]alance sheets have also been rebuilt and leverage is down, indicating ample incentive and scope for expansion."25 It remains to be seen whether the Philippine government will receive the development assistance needed to accomplish its goals in the coming years.

\section{The History of Philippine Labor Migration}

The so-called "structural limitations" of overpopulation, unemployment, and poverty are important prerequisites for labor emigration. However, they do not independently explain the large-scale, patterned exodus of workers from the Philippines. The active intervention of the Philippine government, beginning in the late 1960s, was of greater significance to this phenomenon than any factor cited in traditional theories of migratory behavior.

For example, push-pull theories of labor migration-which explain labor displacement through individual cost-benefit analysis and supply-demand functions-do not explain why other countries with similar or worse economic conditions have failed to produce comparable migration levels. ${ }^{26}$ Similarly, theories focusing on deliberate labor recruitment ignore the fact that migrant flows are not always based on recruitment through economic incentives (e.g., undocumented or "illegal" immigrants, and coerced laborers). ${ }^{27}$ In addition to these structural and functional explanations, social and transnational networks can help explain why migrant flows eventually become self-sustaining, i.e., why such flows persist after the original economic incentives for migration have virtually disappeared. ${ }^{28}$ Although these three theories provide needed insight into the development of Filipino labor migra-

25. Id.

26. Alegado, supra note 8 , at 151. See also Lindquist, supra note 8, at 8-16 (examining the relationship of social networks, government policy, and economic processes involved in international labor migration by focusing on a small town called Ternate in the Philippine province of Cavite).

27. Alegado, supra note 8 , at 152.

28. Id. at 153. See also Lindquist, supra note 8, at 22-29 \& infra pt. I.D. (discussing cultural factors related to labor migration). Prior to the government's adoption of a labor export policy in 1974, the Philippines experienced four types of labor migration: (1) forced or involuntary (e.g., under Spanish colonialism); (2) labor recruitment (e.g., Hawaii sugar/agribusiness and the U.S. Navy); (3) voluntary (e.g., student migration to Europe and the United States, war veterans who fought with the United States, and others who migrated under the 1965 Immigration Act); and (4) refugee movements (e.g., Moslems migrating from the southern Philippines after indiscriminate bombing by President Marcos). Alegado, supra note 8, at 154-69; Lindquist, supra note 8, at 41-49. 
tion, ${ }^{29}$ the most influential impetus came from active governmental intervention. ${ }^{30}$

The 1974 Labor Code was designed to provide a network of public employment controlled by state regulation and supervision. The government hoped to phase out private-sector participation to take full advantage of the growing and lucrative labor exportation trade, while eliminating illegal or unscrupulous recruiters. ${ }^{31}$ However, the government machinery charged with regulating this trade was unable to handle the overwhelming demand for overseas workers. Consequently, when confronted with a vigorous campaign by private recruiting agencies to resume their role in overseas employment, former President Ferdinand Marcos conceded in light of this demand. ${ }^{32}$ In 1978, Presidential Decree No. 1412 removed almost all restrictions on the activities of private recruiters. Also, Presidential Letter of Instruction 852 announced the government's new "Corporate Export Strategy," which was designed to encourage the "grouping" of overseas employment contracts, and to grant incentives to contractors who participated in the scheme. ${ }^{33}$ Presidential Decree 1691, issued in 1980, further amended the Labor Code by requiring the recruitment and placement of workers according to government-to-government arrangements. This requirement resulted in a proliferation of bilateral agreements (BLAs) with Middle Eastern countries. ${ }^{34}$ As a result of continued growth in the market, President Marcos issued Executive Order No. 797 in 1982, which consolidated the existing overseas gov-

29. Lindquist, supra note 8 , at 8,21 (referring to the relationship between these distinct factors as "dialectical"). See also J.E. Smart, Saudi Demand for Filipino Workers: Labor Migration Issues in the Middle East, 9 Asian \& PaCIFIC CEnsus F. 1, 13 (1982) ("[T]he growth of the Philippine component of this labor movement developed with reference to a number of interrelated social, political, and economic issues.").

30. Alegado, supra note 8 , at 169 . See also Lindquist, supra note 8 , at 4-6 (noting that the growing global interdependence of nations produces a need and/or desire for integration through international exchange and circulation, both financial and cultural).

31. Alegado, supra note 8, at 169-72. Then President Ferdinand Marcos created the Overseas Employment Development Board (OEDB) and the National Seamens' Board (NSB) to implement the systematic placement of overseas land-based workers and seamen by the government. The Bureau of Employment Services (BES) under the Ministry of Labor \& Employment (MOLE, now DOLE, the Department of Labor \& Employment), which was already in place and functioning as a transitory government-run employment agency, was extended to regulate private recruiting agencies. See also Lindquist, supra note 8 , at 59.

32. "Today, the private sector is responsible for the placement of ninety-six percent of overseas contract workers." Lindquist, supra note 8, at 65 (quoting Philippine Overseas EmployMent Agency, 1989 Annual RePort).

33. Alegado, supra note 8 , at 174 (noting that incentives were granted through the newlycreated Philippine Overseas Construction Board, which was established to develop, regulate, and monitor the overall performance of the booming overseas construction industry).

34. Id. at 175,180 (stating that by the early 1980 s, the Marcos government had concluded BLAs with the United Arab Emirates, Saudi Arabia, Iraq, Iran, Jordan, Zambia, Algeria, Nigeria, and the Republic of Nauro). 
ernmental activities into a single agency, the Philippine Overseas Employment Agency (POEA). POEA was granted comprehensive authority over migrant contract workers. ${ }^{35}$ During 1983 , in conjunction with major public awareness campaigns, a Labor Assistance Center was created to further combat illegal recruitment. ${ }^{36}$

Although the 1974 Labor Code marked the formal beginning of labor exportation from the Philippines, it was not until 1978 that such exportation became an official component of the national development strategy. Originally viewed as a temporary answer to the country's unemployment and severe balance of payment problems, the export of labor has become an institutionalized and pervasive aspect of the Philippine political economy. ${ }^{37}$ The decisive role of the state in mobilizing and stabilizing the flow of international labor migration from the Philippines resulted in trans-nationalization of a large segment of the working class. However, it did not provide adequate protection of this vulnerable group's interests. ${ }^{38}$

\section{Cultural Factors}

Application of conventional Philippine studies ${ }^{39}$ to the labor exportation problem might lead the casual examiner to conclude that Filipino cultural traits (e.g., their purportedly docile, deferential, and accommodating nature) contribute to the persistence of abuse against them. ${ }^{40}$ Focusing on these "traditional" characteristics, however, ignores the strikingly different values held among Filipinos. These values include the following (in loose translation): respect for rights; equality; dignity; justice; freedom; and the treatment of others as human beings. ${ }^{41}$

When trapped by structural limitations and inefficiencies in their home countries, people often choose to migrate (despite the inherently negative aspects of such action) since it is "not as highly risky, costly and uncertain [an undertaking] as the revolutionary option."42

35. Id. at 176. See infra text accompanying note 78 (describing the POEA's duties). See also Lindquist, supra note 8 , at 60 .

36. Lindquist, supra note 8 , at 60 .

37. Alegado, supra note 8 , at 198 . See also Lindquist, supra note 8 , at 58,61 .

38. See infra pt. III.A. (discussing the social disruption caused despite governmental regulation of the labor-export industry).

39. See, e.g., Frederica M. Bunge ed., Philippines: A Country Study (1983).

40. Compare Benedict J. Tria Kerkvlet, Everyday Politics in the Philippines: Class and Status Relations in a Central luzon Village 243 (1990) (citing various authors) with BUNGE, supra note 39 , at 83.

41. KeRKVLIET, supra note 40 , at $272-73$.

42. Lindquist, supra note 8, at 15 (citing N. Shrestha, A Structural Perspective on Labor Migration in Underdeveloped Countries, 12 Progression In Human Geography 179, 192 (1988)). 
Studies of the export of labor in other countries suggest a recurring pattern in employment overseas: (1) recruiters offer incentives to lure migrant workers; (2) the steady infusion of hopeful migrants allows recruiters to charge fees; and (3) the ultimate over-supply of workers leads to a decline in wages, and increasing incidents of exploitation and loss. ${ }^{43}$ The impetus that starts this dynamic process is identified in the following finding: "Common to all labor exporting nations of Asia, with the exception of Thailand and Korea, is a period dominated by colonization and a subsequently subservient position within the global economic system." ${ }^{44}$ In other words, the penetration of capitalism into traditional societies intensifies existing inequalities between rural and urban communities, and compels people in peripheral, rural societies to move to more developed areas for employment, including overseas locations. ${ }^{45}$ In the Philippines, the labor-intensive, exportoriented strategies championed by the World Bank and International Monetary Fund exacerbated existing structural constraints. ${ }^{46}$ As a result, it became impossible for even skilled Filipino workers to stay in the Philippines and fulfill their expectation of a new lifestyle-a dream that was introduced by the country's colonial dominators.

Undoubtedly, the Philippines' long experience with various forms of migration also has had a significant impact on its citizens' willingness to travel long distances in search of economic security. ${ }^{47}$ The development of social networks extended the accessibility of foreign employment to all classes of society, and linkages to successful overseas emigrants served to increase individual confidence in the prospects for success. The importance of social networks should not be underestimated, and is supported by the fact that structural and functional approaches to labor migration do not explain why some Filipinos fail to emigrate. Despite an almost "universal" desire to go abroad in search of a better future, many Filipinos stay behind because either they do not have the necessary contacts, or they are unwilling to give utang na loob (reciprocity or a debt of gratitude) to the individuals who can facilitate overseas contracts. ${ }^{48}$

43. Id. at 26-27 (quoting A. Singhanetra-Renard, Going Abroad: Thai Labor Movement to the Middle East from the Village Standpoint (Sept. 19-23, 1988) (unpublished paper presented at the Conference on Asian Labor Migration to the Middle East, East-West Population Institute, East-West Center, Honolulu)).

44. Id. at 49 .

45. Id. at $12-13,18$.

46. See Alegado, supra note 8 , at 310 .

47. See supra notes $26-36$ and accompanying text.

48. Lindquist, supra note 8 , at $168-73,182-86$. 


\section{E. Politics}

Today's Philippine political culture has its roots in the hegemonic system established by Spanish rule and monopolized by an elite class known as ilustrado ("the enlightened"). ${ }^{49}$ This small class of landed gentry virtually controlled the vast majority of the Filipino population throughout much of the country's history. Though "democratic" in form, Philippine politics is still substantially one of patronage and privilege. ${ }^{50}$ Ferdinand Marcos' plunder and destruction of the country's political institutions, combined with concurrent and subsequent capital flight, and the inability of Corazon Aquino to project decisive leadership created a climate of insecurity in Philippine society that the current leadership hopes to ameliorate.. 51

A feminist nationalist movement called the Kilusang ng Manggagawa Kababaihan (KMK-Women Workers Movement), which operates as a sub-movement within both the larger labor organization Kilusang Mayo Uno (KMU-May First Movement), and the feminist umbrella organization GABRIELA (General Assembly Binding Women for Reforms, Integrity, Leadership, and Action), keep women's issues alive in the Philippines. However, the feminist political agenda is "simply not considered to be as politically relevant or important as issues of national sovereignty." 52 Consequently, the nationalistic demands typically overwhelm and marginalize feminist concerns. ${ }^{53}$ In direct contrast to their Western counterparts, members of the KMK "believe in the necessity of nationalism to eradicate the colonialism [and associated cultural oppression] which they believe to be one cause of gender [in]equality." 54 Philippine feminists advocate political and economic restructuring while maintaining a cultural tradition of strong family values. ${ }^{55}$

Although the KMK may need to form coalitions with different interest groups before significant social reforms or revolutions can be achieved, the movement remains significant because its efforts (viz.,

49. Belinda A. Aquino, Philippine Feminism in Historical Perspective, in Women and Polı. TICS Worldwide 590 (Barbara J. Nelson \& Najma Chowdhury eds., 1994).

50. Id. at 2. The current president, Fidel Ramos, is "not from one of the elite families, but he is well connected to them." Asia \& PACIFIC Rev. 1993/94, supra note 6, at 213.

51. Aquino, supra note 49, at 3. The author quotes Francisco Nemenzo, arguing that Corazon Aquino's indecisiveness stemmed from a fear of confrontation with both the native elite and the U.S. government: "[Aquino] has desisted from tampering with structures other than those directly linked with Marcos." Id. at 17.

52. Lois West, Political Unionism, Development and Democratization in the Philippines (Temple University Press, forthcoming 1994).

53. Id.

54. Id. at 278-79.

55. Id. at $217,220-21$ (noting that in Philippine society, children are raised not just by their mothers, but also by older children, fathers, or extended kinship/friendship networks). 
analyzing the effects of culture, the internationalization of capitalist markets, women's movements, and their interconnections) may give new meaning to gender relations in the Philippines. ${ }^{56}$ Hopefully, the new approaches generated through these efforts will lead to a greater international awareness of the abuse of working women. However, it will be only after the community of nations recognizes its fundamental and common interest in protecting the vulnerable elements of Philippine society (e.g., migrant workers) that the status quo will be improved.

\section{The Problems and Regulation of Labor Exportation}

\section{A. Social Disruption and the Abuse of Workers}

The Philippine Development Plan for Women notes several socio-physiological problems associated with the exportation of labor:

(1) a disorientation of values resulting from the sudden increase in income from overseas work;

(2) solo parenting and its attendant problems;

(3) emotional pressure, loneliness, and anxiety caused by temporary separation from loved ones;

(4) marital strain and dissolution;

(5) neglect of children;

(6) negative economic dislocation effects on the family; and

(7) inadequate programs for the reintegration of returning workers. ${ }^{57}$

The Plan also states,

[T] he labor migration program may actually be leading to the deterioration of the quality of human resources available for the domestic needs of the country and that it may be 'creaming off' the best workers of the domestic labor force. Distortions in the choice of educational investments are also being sustained by emigration. ${ }^{58}$

\section{Questionable Benefits}

Because the alleged benefits associated with overseas employment have not been seen in the Philippines, the government's labor exportation policy has been subject to much criticism. For example, some Philippine provinces remain brutally poor, despite the fact that hundreds of sons and daughters of their residents have taken overseas jobs during the past fifteen years. ${ }^{59}$ Meanwhile, the human costs of

56. Id. at 280.

57. National Commission on the Role of Filipino Women, Philippine Development Plan for Women 1989-92, 124 (1989) [hereinafter Development Plan for Women].

58. Id. at 123.

59. Abby Tan, Paychecks Sent Home May Not Cover Human Losses, L.A. Times, Oct. 1, 1991 , at 2. 
delinquent children, drug abuse, rampant crime, broken homes, poverty, and unemployment remain crucial problems for those left behind.

While migrant labor may provide economic benefits to individual families, it fails to provide social mobility to [many] workers . . . [who return to the Philippines and] find themselves in a vicious circle, ... a two year contract would be enough to just pay off the debts they incurred to get their job in the first place. ${ }^{60}$

Whether the economic benefits the government receives from remittances outweigh the physical and psychological problems associated with the export of labor is also debatable. The government still has no system in place to collect taxes from many contract workers, and many workers do not send money home through the official banking system. ${ }^{61}$ The primary concerns that prevent full use of official bank channels are speed, cost, and safety. ${ }^{62}$ For example, (1) some worksites have no banking facilities, which results in three- to sixweek delays in check-cashing; (2) remitting banks often are characterized by inefficiencies such as faulty transmissions; and (3) local banks sometimes are unwilling to act as conduits because of time demands and prohibitive telex costs. ${ }^{63}$ The Philippines also does not have enough concrete projects designed to ensure that overseas earnings are channeled to productive investments. A booklet entitled The Labor Trade notes that little of the money sent back, even through official channels, winds up financing new factories or businesses that might result in more jobs at home for the next generation of Filipinos: ${ }^{64}$ "It is a myth that remittances lead to domestic capital formation. It is also false that labor export has solved the problem of unemployment." 65

\section{Exploitation of Filipina Workers}

Women and girls in the lower economic strata are especially vulnerable to exploitation in the Philippines. While unethical operators may promise legitimate employment in Manila or overseas, or may arrange marriages with foreign men, some women end up working as prostitutes or suffering abuse at the hands of their employers or husbands. ${ }^{66}$ Many observers believe that an increasing amount of mi-

60. Id.

61. Id.

62. Alegado, supra note 8, at 191.

63. Id.

64. Tan, supra note 59 , at 2 .

65. Id.

66. U.S. Department of State, Human Rights Condminon: Annual Country RePORTS 1014 (1990) (pursuant to the Trade Act of $1974 \S 505(\mathrm{c})$ ). 
grant labor involves women. ${ }^{67}$ An export program that feeds attractive Filipinas to Japan's thriving sex industry results in countless instances of victimization.

For example, rather than pursuing a career as an entertainer, fifteen-year-old Noini Buendia ended up at a degrading brothel in Japan, where she was beaten and raped by brutal customers. ${ }^{68}$ Buendia recalled her arrival at a club located five hours outside of Tokyo:

It was a maze of rooms. The papa-san said, "Get dressed, you're going to work right away." I was tired from the trip, but I obeyed. I took a shower, put on my best dress and my best makeup. The papa-san came back and said, "You're ready?" I wanted to follow him down to the dance floor, but he said, "Wait here" and closed the door. I knew then something was wrong. I took out my rosary and began to pray. Then the door opened and a very fat and ugly Japanese man came in. He was old. He just looked at me and pushed me onto the bed. I struggled and yelled, but no one heard me. He raped me. I was still a virgin then. I know now he paid between $\$ 2,000$ and $\$ 3,000$ for a first night. For the next four months, I was locked in that room. A guard was on the floor outside. Each night, three, four sometimes five men would come in and have sex with me. I just let it happen. They could do with me what they wanted. There was no one I could protest to. ...

Some customers left a tip, but the guard took it. I wouldn't touch it. I never talked to anyone in those four months, not even the clients. I never saw daylight in those four months. There was no window in my room....

One night the guards and the papa-san dragged a Filipina along the corridor by her hair. They beat and kicked and cursed her as if she was a man. I think she tried to run away. I never thought of running away again. ...

None of us will complain because the authorities will laugh at us and say: "Why did you go?" ... Everyone here pretends. That's the way it is ....69

Noini was eventually rescued by a sympathetic client, who snuck her out of the brothel and paid for a plane ticket to help her get out of the country. But the young lady later returned to Japan for three more six-month tours. During the interview quoted above, she was waiting for her fourth visa. Already abused and degraded, and saddled with

67. Development Plan for Women, supra note 57, at 119.

68. Uli Schmetzer, Filipina Girls Awaken to a Nightmare in Japan, CHI. TRIB., Nov. 20, 1991, at 1. Another revealing article cites statistics showing Filipino overseas contract workers to have an AIDS infection rate of $22 \%$, which is a rate greater than that of prostitutes. Filipino Contract Workers Warned of AIDS Infection, Xinhua General Overseas News Service, Dec. 19, 1991, available in LEXIS, Nexis Library, Xinhua file.

69. Id. 
the responsibility of educating her four siblings, Noini Buendia continues her life of prostitution.

\section{B. Philippine Overseas Employment Regulations}

The Philippine government's early attempts to exercise total control over the overseas labor export industry overstretched its administrative capabilities. Consequently, in 1978 the government began to encourage private participation once again. ${ }^{70}$ Nonetheless, the government maintains an active role in the governance of overseas workers. Under the Philippine Labor Code, regulatory jurisdiction over this industry lies with the Department of Labor and Employment (DOLE). Meanwhile, the Department of Foreign Affairs (DFA) plays a subsidiary role both in the promotion of employment opportunities and the protection of workers. This division of responsibility sometimes leads to conflicts in policy formulation and divergent responses to emerging problems. DFA embassy personnel often are more aware of the difficulties that need to be addressed, but they only have authority to suggest appropriate remedial action to decisionmakers who are far removed from the issues. In addition, overseas workers often conclude that it is not in their best interest to seek assistance from the Philippine government, since it may result in termination or deportation. At the same time, the government may determine that it is not in its best interest to pursue an individual case against a labor-importing state.

\section{Government Entities}

a. The Department of Labor and Employment

DOLE pursues three goals, in order of priority they are: (1) employer protection and manpower development; (2) the maintenance of industrial peace; and (3) worker protection and welfare. ${ }^{71}$ Although Corazon Aquino's first labor minister, Augusto Sanchez (a former human rights lawyer), was a strong advocate of workers' interests, ${ }^{72}$ he was dismissed in an attempt to quell the continuing unrest that followed an unsuccessful military coup attempt in November $1986 .^{73}$

70. See supra notes $32-33$ and accompanying text.

71. Phil. Dep't of Lab. \& Employment, 1987 annual Report 10.

72. West, supra note 52, at 324. See also New Challenges Face MOLE Head, 12 PHIL. LAB. 1 (1986). Sanchez believed that "structural imbalances" were the root cause of workers' poverty, and advocated profit-sharing as a way to increase productivity. The number of strikes in the Philippines rose dramatically under Sanchez, prompting the business sector to organize against what it felt was an unfavorable investment climate. WEST, supra note 52, at 327.

73. "Aquino asked for the resignation of Juan Ponce Enrile and Augusto Sanchez-one cabinet member from the right, one from the left." WEST, supra note 52, at 328. 
Subsequent labor department heads (Franklin Drilon and his replacement Reuben Torres) identified more closely with business interests. ${ }^{74}$ Although the current Secretary of Labor, Nieves Confesor, has impressive academic credentials and substantial in-house experience at DOLE ${ }^{75}$ only time will tell how successful she will be in striking a balance between economic development and the protection of workers' welfare. ${ }^{76}$

The Philippine Overseas Employment Agency, which was created under DOLE in $1982,{ }^{77}$ consolidated existing entities and assumed additional functions. POEA's duties are to:

(1) establish and maintain a registration and/or licensing system to regulate private sector participation in the recruitment and overseas placement of workers;

(2) maintain a registry of skills for overseas placements;

(3) recruit and place trained and competent Filipino workers;

(4) promote the development of skills and careful selection of Filipino worker[s] for overseas employment;

(5) undertake overseas market development activities for placement of Filipino workers;

(6) secure the best possible terms and conditions of employment for Filipino contract workers and ensure compliance therewith;

(7) generate foreign exchange from the earnings of Filipinos employed under its program; and

(8) promote and protect the well-being of Filipino overseas workers. ${ }^{78}$

To carry out these duties, POEA utilizes three major offices organized around specific functions. These offices include:

74. Id. at 333.

75. See Reyes, supra note 10 , at 30 . Secretary Confesor holds master's degrees in business administration (Ateneo Graduate School of Business), Asian studies (University of the Philippines), and public policy (John F. Kennedy School of Government, Harvard University). Furthermore, she has seen the shifts in economic and social policy during her tenure at DOLE (from 1976 to the present) under the diverse approaches of Sanchez, Drilon, and Torres, as well as Blas Ople during the Marcos Administration. Id.

76. Secretary Confesor places particular emphasis on the promotion of livelihood projects and self-employment schemes, because of her firm belief in the theory that government should be a minimal player in actual economic activities. On the other hand, she admits that the welfare of overseas workers, particularly women, must be protected. For example, Confesor supports the National Manpower and Youth Council's women-in-trades program (WINT). Under this program, women are trained in skills that used to be a traditional preserve for men; the program expands the marketability of women workers, equalizes job opportunities, and breaks deeplyrooted sexual divisions of labor. Id. Confesor believes that labor policy has its moorings in economic and social policy, not the other way around. Full employment and industrial peace are not ends in themselves but merely means for achieving social justice. In her mind, respect for workers' welfare is the best evidence of a just society. Id.

77. See supra note 35 and accompanying text (mentioning the executive order that created the POEA); see also pt. III.A.3. (discussing the Overseas Workers' Welfare Administration, which was responsible for developing and managing an overseas workers' welfare fund).

78. Alegado, supra note 8 , at 175 . 
(1) the Market Development and Placement Office, which is in charge of conducting systematic manpower recruitment, processing, deployment, and marketing programs;

(2) the Workers' Assistance and Adjudication Office, which promotes and protects the welfare of overseas workers and their families; and

(3) the Licensing and Regulation Office, which conducts inspections and establishes standards of development. ${ }^{79}$

POEA also established a Regional Labor Center for the Middle East and Africa, with areas of operation including Saudi Arabia, Kuwait, Bahrain, Qatar, Oman, United Arab Emirates, Iraq, Jordan, Lebanon, Iran, North and South Yemen, Nigeria, Malta, and Cyprus. The Center's duties include maximizing employment and contracting opportunities for Filipino workers, in addition to coordinating the Department of Foreign Affairs' Labor Attaché ${ }^{80}$ activities on employment promotion and workers' protection. ${ }^{81}$

Other entities under the umbrella of the POEA include Philippine Overseas Construction Administration (POCA) and the National Manpower and Youth Council (NMYC). These organizations are responsible for those aspects of the country's labor export policy that are concerned with generating employment opportunities and training workers. Finally, the inter-agency One-Stop Documentation Center (which is run by DOLE, DFA, and the Department of Tourism) expedites the processing and documentation of contract workers' employment and travel papers prior to overseas deployment, while the Labor Assistance Center facilitates the deployment and reception of workers at the Manila International Airport. ${ }^{82}$

\section{b. The Department of Foreign Affairs}

In conjunction with the Philippine Central Bank, DFA is charged with monitoring and systematizing the flow of remittances and taxes from overseas Filipino workers. ${ }^{83}$ When DFA was reorganized, ${ }^{84}$ its emphasis shifted from purely political, traditional consular and diplomatic work to an agenda that includes the pursuit of the economic objectives sought under the country's development strategy. It took some time to address the unfamiliar demands of this new role, and some of the resulting problems remain evident.

\footnotetext{
79. Id. at 178 .

80. See infra text accompanying notes 85-88 (discussing the Labor Attaché program).

81. Alegado, supra note 8, at 178-79.

82. Id. at 179.

83. Id.

84. Id. at 194 (citing Phil. Exec. Order No. 523 (1979)).
} 
A "Labor Attaché" program was formed to assist with systematic deployment, market development, the monitoring of workers and their remittances, the enforcement of government policies, general legal and welfare assistance, and the collection of taxes. Currently, several Regional Labor Centers are operating in the Middle East, North Africa, and Europe. ${ }^{85}$ Government-provided on-site "assistance and services to overseas workers through Labor Attachés and the Filipino Workers' Social Centers . . . are, [however,] inadequate considering the number of countries where Filipino workers are employed." ${ }^{86}$ Furthermore, normally only one labor attaché is assigned to a country (with the exception of Saudi Arabia which has three labor attachés posted in Riyadh, Jeddah, and Al-Khobar). These individuals operate alone, and because of their limited funding, are not able to hire local personnel necessary to operate effectively. ${ }^{87}$ Nonetheless, the labor attachés and embassy personnel can play important roles in goading Philippine leaders into action. For example, in November 1991, the Philippine Embassy in Islamabad urged a ban on sending Filipino women to work as maids in Pakistan and "rigidly Islamic countries," following complaints of maltreatment and sexual abuse at the hands of employers. ${ }^{88}$

\section{Methods of Regulation}

In response to mounting publicity concerning the abuse of Filipina entertainers in Japan, ${ }^{89}$ on November 20, 1991, the Philippine government imposed severe restrictions on the overseas employment of women under the age of twenty-three. ${ }^{90}$ Under the ban, work visas are permitted only for women over twenty-three who have performed for at least one year in a reputable Philippine establishment as either a

85. Id. at $178,195$.

86. Development Plan for Women, supra note 57, at 124 (emphasis added). Although one of the Regional Labor Centers' responsibilities is to coordinate labor attache activities (including workers' protection as well as employment promotion), the breadth of responsibilities and minimal resources contributed make it unlikely that significant worker protection will or can be accomplished by the Centers. Id.

87. Id.

88. Clift, supra note 3.

89. See, e.g., supra pt. III.A.2.; see also supra notes 3, 68; infra notes 90, 93, 195 (citing relevant newspaper articles).

90. Clift, supra note 3. President Aquino approved the restrictions following a national outcry after a young Filipina dancer, Maricris Sioson, died while working as a dancer in a Japanese discotheque. The woman's employers said she died of hepatitis, but a Philippine coroner indicated that her body bore signs of abuse. Id. See also Philippines to Keep Partial Ban on Sending Workers to Japan, Kyodo News Service, Oct. 24, 1991 (indicating that Sioson suffered stab wounds, bruises, and massive head injuries). 
musician, singer, or dancer. ${ }^{91}$ However, since about 40,000 Filipina entertainers work in Japan illegally, ${ }^{92}$ the restrictions will probably have a limited impact. It is noteworthy that the Secretary of Labor, POEA, and many entertainers opposed earlier proposals seeking a complete ban, arguing that the Philippines' need for the money sent home by these women overrode any other concerns. ${ }^{93}$

The initial process of screening overseas entertainers involves a panel of five government judges that conducts daily "quality control" auditions for the 40,000 "entertainers" or "cultural dancers" who seek foreign work permits every month. ${ }^{94}$ Those who pass inspection receive a coveted yellow card, which is required under a bilateral agreement for Japanese employment and certifies that the young girl is an "entertainer" or "cultural dancer." Candidates are then driven to a motel to audition for Japanese entrepreneurs, where their teeth are examined and their medical certificates checked to verify that they are not pregnant. ${ }^{95}$

The specific rules and regulations governing overseas employment are promulgated by the Governing Board of POEA, in accordance with the agency's interpretation of relevant provisions in the Labor Code. ${ }^{96}$ POEA's rules are organized as follows:

$\begin{array}{ll}\text { Book I } & \begin{array}{l}\text { General Policy } \\ \text { Licensing and Regulation } \\ \text { Book II } \\ \text { Book III }\end{array} \\ \text { Market Development and Placement by the } \\ \text { Pook IV } & \begin{array}{l}\text { Market Sector } \\ \text { Administration }\end{array} \\ \text { Book V } & \text { Standards for Employment and Placement by the } \\ \text { Book VI } & \text { Adjudication Rules } \\ \text { Book VII } & \text { Worker's Assistance and Welfare Services } \\ \text { Book VIII } & \text { Transitory and Miscellaneous Provisions. }{ }^{97}\end{array}$

Each of these categories encompasses a wide variety of measures designed to address problems with the Philippine labor export indus-

91. After a total ban was rejected, Aquino imposed a partial ban on October 16, 1991, covering Fukushima prefecture in northeastern Japan. Clift, supra note 3.

92. Id.

93. Philippine Go-Go Dancers Protest Against Japan Ban, Reuter Libr. ReP., Nov. 18, 1991; Torres Opposes Ban on Filipina Entertainers to Japan, Kyodo News Service, Nov. 13, 1991.

94. Id.

95. Id.

96. See infra text accompanying note 146 (listing provisions of the Labor Code related to recruitment and placement of overseas workers).

97. LABOR CODE, supra note 9, at 588-620. 
try. Book VII, however, recognizes POEA's obligations to overseas workers, as well as the reciprocal obligation of workers to remit a specified percentage of their annual earnings to the Philippine government. Its contents include:

\begin{tabular}{|c|c|}
\hline Rule I & Assistance to Workers ${ }^{98}$ \\
\hline Rule II & Pre-departure Orientation Seminar (PDOS) ${ }^{99}$ \\
\hline Rule III & $\begin{array}{l}\text { Duties, Obligations and Code of Discipline for } \\
\text { Filipino Overseas Workers }{ }^{100}\end{array}$ \\
\hline Rule IV & $\begin{array}{l}\text { Conduct of Medical Examination for Overseas } \\
\text { Workers }{ }^{101}\end{array}$ \\
\hline Rule V & Performance Bonds for Workers ${ }^{102}$ \\
\hline Rule VI & $\begin{array}{l}\text { Mandatory Personal Accident and/or Life } \\
\text { Insurance, War Risk Insurance and War Risk } \\
\text { Premium Pay }\end{array}$ \\
\hline Rule VII & Manpower Pool ${ }^{104}$ \\
\hline Rule VIII & Certification of Entertainers ${ }^{105}$ \\
\hline Rule IX & Training for Overseas Employment ${ }^{106}$ \\
\hline Rule X & Foreign Exchange Remittance. ${ }^{107}$ \\
\hline
\end{tabular}

Internal POEA Circulars and Memorandum Orders reflect the agency's efforts to follow these rules and provide a quick method for it to react to developments that adversely affect overseas workers. ${ }^{108}$

98. Responsibilities under the rules include: (1) agencies or entities (recruiters) shall ensure deployed workers are amply protected, and are responsible for faithful compliance by foreign principals with all obligations (including liability for violations); (2) POEA shall provide the worker and his family with all the assistance needed to enforce contractual obligations by recruiters or their principals; (3) POEA shall, in coordination with other governmental institutions, assist on other matters arising out of overseas employment; (4) repatriation shall be the primary responsibility of the recruiter (costs covered by recruiter or its principal); (5) recruiters shall, in coordination with POEA, initiate and undertake projects and activities to enhance the welfare and interests of workers at overseas job-sites and their families. Id. at 610 11.

99. POEA-approved PDOs must be provided by the recruiter free of charge. Id. at 611-12.

100. Id. at $612-14$.

101. Id. at 614-15.

102. Id. at $615-16$.

103. The employer must provide, at no cost to the worker, accident or life insurance (minimum 50,000 pesos) and war risk insurance (minimum 100,000 pesos). Coverage is required for the duration of the contract, and prompt payment is insured by the recruiter. Id. at 616 .

104. Id. at 616-17.

105. Id. at $617-18$.

106. Id. at 618 .

107. Id. at 619-20. The percentage of a worker's basic salary that is required to be remitted is as follows: (1) seaman or mariners- $80 \%$; (2) workers of Filipino contractors and construction companies-70\%; (3) doctors, engineers, teachers, nurses, and other professional workers whose employment contracts provide for free board and lodging-70\%; (4) the above-mentioned workers whose employment contracts do not provide for free board and lodging- $50 \%$; (5) all other professionals without free board and lodging-50\%; (6) domestic and other service workers- $50 \%$; (7) all others- $50 \%$.

108. See id. at 621-29 (containing a compilation of these items). 
For example, in 1986, deployment to certain areas of Angola was suspended. ${ }^{109}$ Later that same year, POEA's Administrator wrote, In view of the mounting Welfare problems encountered and reported by our Philippine embassy in Kuwait and the subsequent strong recommendation of the Ministry of Foreign Affairs it is hereby ordered that the deployment of FEMALE DOMESTIC WORKERS to said job-site shall be temporarily suspended. Lifting of the suspension shall be contingent on the passage of a Kuwaiti law affecting such workers and subsequent arrangements will be pursued by the Philippine Government to protect and control the deployment in consultation with the Kuwaiti government. ${ }^{110}$

\section{Methods of Enforcement}

It is interesting to note that although remittances ${ }^{111}$ have been mandatory since 1968 , sanctions have applied only since December 1982. ${ }^{112}$ When first implemented, the use of sanctions touched off a huge controversy. The International Labor Organization (ILO) protested that it was "incompatible with Article 6 of ILO Convention No. 95 on the Protection of Wages[,] . . . a convention the Philippines ratified and which states [that] '[e]mployees shall be prohibited from limiting in any manner the freedom of the worker to dispose of his wages.' "113

With regard to other matters, POEA has "original and exclusive jurisdiction to hear and decide all cases involving employer-employee relations arising out of or by virtue of any law or contract involving Filipino workers for overseas employment." ${ }^{114}$ Such complaints must be filed with POEA's Adjudication Department, and the accused must respond within ten days. ${ }^{115}$ Self-help measures, on the other hand, are usually impracticable for individual workers. The legal process is expensive and circuitous, and the adjudication of cases in host

109. Id. at $651-52$ (referring to Memorandum Circular No. 13 (July 15, 1986)).

110. Id. at 657 (referring to Memorandum Circular No. 22 (Sept. 12, 1986)).

111. See supra note 107 (listing the required remittances, in percentage of salary, for specific occupations).

112. Executive Order No. 857 called for non-renewal of passports, cancellation of licenses for agencies who failed to comply, and the use of embassy facilities to remit earnings if no banking sites were available. Alegado, supra note 8 , at 192-94.

113. Id. at 193-94. The order was repealed in May 1985, but its less drastic replacement, Executive Order No. 1020, actually retained the mandatory provisions. Id. at 194.

114. LABOr CODE, supra note 9, at 606. Book VI, Rule I (Jurisdiction and Venue) states that POEA jurisdiction includes, but is not limited to, cases or controversies involving: (1) violation of terms; (2) implementation and interpretation disputes; (3) money claims against employers and their agents; (4) claims for death, disability, and other benefits arising out of employment; (5) violations of, or non-compliance with, compromise agreements; and (6) disciplinary cases. Id.

115. Id. (permitting any contract worker, heirs or beneficiaries, licensed agency, or foreign or local employer to file such a complaint via Rule II and III). 
countries may be problematic since the Philippine embassies are often not equipped to deal with the nuances of such cases. ${ }^{116} \mathrm{~A}$ genuine fear of publicity and retaliation also hinders full reporting by victims of abuse, ${ }^{117}$ and therefore the cycle of exploitation continues unchecked.

One reason victims choose to remain silent is the constant threat of deportation by the host state, a practice that is often exercised arbitrarily. ${ }^{118}$ Japanese immigration law specifically provides for deportation of foreigners determined to be in violation of its provisions, ${ }^{119}$ and "immigration control officers may detain individuals" if they have reason to suspect a violation. ${ }^{120}$ Victims of abuse are obviously unemployed once they are deported, but they also face the added hardship of effectively forfeiting any civil or criminal claims they may have had against their former employers. ${ }^{121}$

Although the treatment of women and overseas workers has improved since the previous administration (the Marcos regime exacerbated the "flesh trade" by vigorously promoting "sex tourism" to earn dollars for the ailing economy), ${ }^{122}$ it is not always in the best interest of the Philippine government to argue on behalf of its workers' interests. Other countries that compete with the Philippines in the foreign labor market are often willing to complain less to obtain a better contract. For example, when the Philippine government backed its citizens' demands for higher wages in Singapore, the Singapore government turned to Sri Lankan and Indonesian workers for employment at lower wages. ${ }^{123}$ This reaction was "merely a repetition of what happened a few years earlier to Filipino construction workers[; . . . their pressure for higher wages was defused with the government's importation of Thai workers who were willing to accept lower

116. Development Plan for Women, supra note 57, at 123.

117. Id.

118. Id. at 281 (commenting on the Filipino experience in Taiwan). "The only possible sanctions[, however,] are the requirements to pay undeclared taxes and possible difficulty when applying for reentry." Id. (quoting Clark Roberts, Workers: Foreign and Cheap, BANG (Taipei), Nov. 1988).

119. Marilyn Selby, Human Rights and Undocumented Immigrant Workers in Japan, 26 STAN. J. INT'L L. 325, 327 (1989).

120. Id. at 338 (emphasis added).

121. Id. at 364. A Japanese attorney "can recount many . . cases that were put in the permanent 'pending' file by prosecutors or civil cases that could not be brought because of the victim's deportation." Id. (quoting an interview with Mizuho Fukushima in Tokyo, Japan, on December 26, 1988).

122. Aquino, supra note 49 , at 11 .

123. Walden Bello \& Stephanie Rosenfeld, Dragons in Distress: Asia's Miracle ECONOMIES IN CRISIS 314 (1990) (relying upon views of Filipino domestics in Singapore). 
wages." 124 In addition, controversial economic, social, cultural, or political factors may make foreign worker protection a low priority in the host countries.

\section{Illegal Recruitment}

As noted in Part III.A. ${ }^{125}$ one of the most visible problems associated with the Philippines' labor export program is the prevalence of illegal recruiting activity.

\section{Types of Recruitment Violations}

Illegal recruitment takes place in all areas of overseas employment. Perpetrators of these crimes "appear to be operating through some closely knit and sophisticated mechanism at both the national and international levels." 126 It is not uncommon for unscrupulous recruiters to charge overseas contract workers more than is allowed under the law. Recruiters charge workers "representation costs" to entertain principals from foreign countries, basic fees up to 20,000 pesos to arrange overseas employment contracts (despite a maximum allowable fee of 5000 pesos), and "cost for documentation," which can include police clearance fees, medical examination fees, passport fees, and airport terminal fees. ${ }^{127}$ Misrepresentation by recruiting agencies can lead to stranding (no contract on arrival), contract substitution after the worker arrives overseas, and even imprisonment and/or deportation: ${ }^{128}$ "Despite well-publicized campaigns against illegal recruiting practices, frauds, outright exploitation, and the countless tales of thousands of victims themselves, the incidence of illegal recruiting goes unabated to this day."129

\section{Degrees and Methods of Regulation or Control}

The basic standards, rights, and obligations governing recruitment are set out in the Philippine Labor Code and in the rules and regulations promulgated by POEA ${ }^{.130}$

Being foreigners and strangers in another country and lacking in any legal or political rights, overseas Filipino workers are forced to

\footnotetext{
124. Id. at 314-15 (quoting a Filipino seaman during an interview in Singapore on April 10, 1988).

125. See supra text accompanying note 66.

126. Development Plan for Women, supra note 57, at 123.

127. Alegado, supra note 8 , at 185 .

128. Id. at $185-86$.

129. Id. at 173 .

130. See supra text accompanying notes $96-111$ and $114-15$; infra pt. III.A.1. (identifying provisions of the Philippine Labor Code governing overseas employment and providing for the protection of worker welfare and rights).
} 
swallow their pride and accept these unjust conditions of employment. And given the fact that they had already spent a considerable amount of money in getting the overseas job in the first place, Filipino workers are faced with very little choice but to submit to the demands of their employers. Unfortunately, complaints brought by overseas Filipino workers to the attention of representatives of the Philippine government in their host countries have proven very futile. ${ }^{31}$

As noted in Part III.B.2., the government has also taken direct, immediate action to regulate overseas employment activities. President Corazon Aquino approved a selective ban preventing entertainers under twenty-three years of age from working in Japan and other foreign countries in 1991.132 Similar action was taken in January 1988, when a temporary ban (moratorium) was imposed prohibiting Filipinas under the age of thirty-five from contracting to work as domestic help. ${ }^{133}$

The Philippine government also attempts to prevent abuse through non-regulatory actions. Advertisements were purchased by the Department of Labor warning jobseekers that Japanese society would scorn them as outsiders. POEA's Office of Workers Welfare Administration (OWWA) further clarified this warning by informing the public that Japan's new immigration law, which severely penalizes illegal aliens, would increase the exposure of Philippine entertainers to exploitation and sexual harassment. ${ }^{134}$ OWWA also recommended that all Filipinos going to Japan carry valid visas, deal only with a licensed recruitment agency, get a specific contract, and learn the Japanese language and customs. ${ }^{135}$

\section{Sub Rosa Activities}

The benefits from supplying labor to overseas employers, and the widespread desire by many Filipinos to enter this limited market, often leads to hidden forms of exploitation. Rosa Leynes and seven other teenagers were brought to Manila by an agent, and put up in a

131. Alegado, supra note 8, at 186 (citing Phil. Migration Rev. (2nd Qtr. 1990)).

132. Clift, supra note 3. At least 80,000 Filipinos work in Japan, and at least half illegally. While some are engineers, computer analysts, English teachers, company personnel and trainees, more than $90 \%$ are entertainers and dancers. Id. at 5 .

133. See, e.g., A Maidenly Diaspora, The Economist, Feb. 20, 1988, at 33. For the public reaction, see A Domestic Problem, FAr E. Eco. Rev., Mar. 17, 1988, at 14, 19.

134. Clift, supra note 3.

135. Id. Japan's marriage laws do not favor foreigners, who can lose their resident status if they are divorced. OWWA also said that the illegal status of many Filipinos in Japan exposes them to cruelty and sexual harassment - as a result of rising costs, many clubs have forced entertainers to work longer hours, and many were forced to go out with customers and fined if they refused. $I d$. 
room of his suburban home while they prepared for an audition. The group was "civilized" for two months, taught how to use makeup, serve tea, pour drinks, how to dress, how to strut on high heels, how to bow, and how to wipe drinking glasses. ${ }^{136}$ Rosa recalled that, "every day we signed chits for food, accommodation and dance lessons. All those chits, our airfare and document expenses would come out of our wages. But we only realized that later." 137 Examples like this reflect the exploitation of rural Filipinas who are not familiar with either their own rights or the recruiters' obligations. However, even knowledgeable would-be overseas workers submit themselves to unscrupulous recruiters to bypass regulations that prevent or limit their overseas employment options.

As discussed above in Part I.C. and I.D., ${ }^{138}$ overseas employment is also facilitated by social networks. Clandestine workers depart the Philippines on either tourist or education visas, and then seek work as illegal or undocumented aliens upon arrival at their foreign destinations. ${ }^{139}$ These "tourists" and "students" meet up with contactsoften friends, relatives, or acquaintances - who are already working in the foreign country and can help facilitate appointments with potential employers. Because they lack legal status, these overseas workers lose the protection of any labor rights afforded to employees in the host state. "Because they fear exposure and deportation, these workers do not report employers who abuse them, withhold their wages, deny them accident insurance or fire them because they have been injured on the job and need time to recuperate." 140 As noted in the previous section, Japanese immigration law is especially harsh on undocumented workers - it "imposes criminal sanctions on offenders but does not provide corresponding criminal procedure protection." 141

Furthermore, since corruption and graft characterize portions of the Philippine government, exploited workers often find it more worthwhile to deal with the abuse themselves. Indeed, such workers are often correct in their belief that bribes will induce officials to look the other way, thus leaving the victims of abuse without protective recourse.

136. Schmetzer, supra note 68 , at 6 .

137. Id.

138. See supra text accompanying notes $28-29$ and 47-48.

139. Selby, supra note 119 , at 341 .

140. Id. (referring to the Kinbenren Kokusai Jinken Presymposium Dai-ni Bukai [Kinki Bar Association International Human Rights Presymposium Division Two], Kinki Bengoshikai Rengokai [Kinki Bar Association], and Gaikokujin no Jinken [Foreigners' Human Rights Organization].

141. Id. at 342 . 


\section{Protection of Overseas Workers}

\section{A. Mechanisms Available Within the Philippines}

\section{Laws Concerning Migratory Workers and Their Recruitment}

The Philippine legal system provides several potential sources of protection for worker rights. ${ }^{142}$ For example, Article II of the Philippine Constitution provides,

The State shall promote a just and dynamic social order that will insure the prosperity and independence of the nation and free the people from poverty through policies that provide adequate social services, promote full employment, a rising standard of living and an improved quality of life for all. ${ }^{143}$

The State affirms labor as a primary social and economic force. It shall protect the rights of workers and promote their welfare. ${ }^{144}$

Pursuant to these constitutional requirements, the Philippine government has enacted and promulgated various laws, rules, and regulations to provide needed worker protection. A title entitled the Recruitment and Placement of Workers is prominently placed in the Labor Code. ${ }^{145}$ Regulation of these activities is covered in Chapters II and III of this title, which include the following articles:

Art. 25 Private sector participation

Art. 26 Travel agencies prohibited to recruit

Art. 27 Citizenship requirement

Art. 28 Capitalization

Art. 29 Non-transferability of license or authority

Art. 30 Registration fees

Art. 31 Bonds

Art. 32 Fees to be paid by workers (not to be charged until employment has been obtained or commenced)

Art. 33 Reports on employment status

Art. 34 Prohibited practices-

(a) charging fees larger than [5,000 pesos];

(b) providing false notice, through any information or

(c) activities for the purpose of securing license/ authority;

142. See LABOR Code, supra note 9, at 135-65, 165-264, 264-330 (citing Book II: Human Resources Development Program; Book III: Conditions of Employment; and Book IV: Health Safety and Social Welfare Benefits).

143. PhIL. Const. art. II, \& XI (emphasis added).

144. Id. art. II, \& XVIII (emphasis added).

145. LABOR Code, supra note 9, at 74-85 (Book I, Title I). 
(d) inducing employed workers to quit, unless done to liberate same worker from oppressive terms and conditions of employment;

(e) influencing employers to refuse employment for workers not using a particular agency;

(f) recruiting or placing Filipinos in jobs harmful to public health or morality, or to the dignity of the Republic of the Philippines;

(g) obstructing DOLE inspections;

(h) failing to file required reports;

(i) substituting contracts without DOLE approval;

(j) establishing relationships with travel agencies;

(k) withholding or denying travel documents prior to departure, except as specifically authorized.

Art. 35 Suspension and/or cancellation of license of authority

Art. 36 Regulatory power

Art. 37 Visitation power (inspection by DOLE at any time)

Art. 38 Illegal recruitment (which constitutes economic sabotage when committed by unlicensed entities, regardless of their size)

Art. 39 Penalties-

- Economic sabotage (life imprisonment and [100,000 pesos]);

- License holder violation (two to five years imprisonment and/or [10,000-50,000 pesos]);

- Unlicensed violation (four to eight years imprisonment and/or [20,000-100,000 pesos]);

- Responsible corporate officers (penalty plus deportation for alien violators);

- Automatic revocation and forfeiture of bonds.

POEA also has promulgated licensing regulations governing recruitment, placement agencies, and their activities. Book II of POEA's New Rules and Regulations Governing Overseas Employment includes the following rules:

Rule I(1)(b) In order to participate, private agencies must demonstrate a minimum capitalization of $[500,000$ pesos].

Rule II The issuance of License and Authority requires private agencies to demonstrate that they are "verified undertakings." A guarantee of compliance with existing labor and social legislation must be backed by a cash bond of 100,000 pesos and surety bond of $[150,000$ pesos $]$ in order to answer any claims arising from violations. 
Rule III Providing for liberal inspection of recruiting agencies and other related entities.

Rule IV Permitting recruiters to charge workers Placement and Documentation Fees in limited situations (with a provision for deductibles), and requiring that a service or manning fee be charged to the principals.

Rule V Defining "Illegal Recruitment" (incorporating Article 34 of the Labor Code) and authorizing arrest, seizure, and closure under proscribed circumstances.

Rule VI Suspension, Cancellation, or Revocation of License or Authority on the following grounds: excess fees charged; misrepresentation; inducing employed workers to transfer into less advantageous jobs; influencing or attempting to influence prevention of employment; recruiting or placing workers in jobs harmful to health or morality; obstructing inspections; substituting contracts; failing to report to DOLE/POEA; falsifying worker documents; withholding salaries or remittances without justification (among others). ${ }^{146}$

\section{Labor Laws with Extraterritorial Application}

POEA defines "Employer" to mean "any person, partnership or corporation, whether local or foreign, directly engaging the services of Filipino workers overseas." 147 More importantly, Article XIII, Section III of the Philippine Constitution states that "the State shall afford full protection to labor, local and overseas, organized and unorganized, and promote full employment and equality of employment opportunities."148 This constitutional requirement is codified at Article 12 of the Labor Code, which notes that it is the policy of the State:

(b) To protect every citizen desiring to work locally or overseas by securing for him the best possible terms and conditions of employment;

(f) To strengthen the network of public employment offices and rationalize the participation of the private sector in the recruit-

146. Id. at 589-99.

147. Id. at 588 (Book I, Rule II(1)(1): New Rules and Regulations on Overseas Employment) (emphasis added).

148. PhIL. Const. art. XIII, \& III (emphasis added). 
ment and placement of workers, locally and overseas, to serve national development objectives. ${ }^{149}$

These policies are given effect in Article 17, which states that it is POEA's power and duty "to secure the best possible terms and conditions of employment of Filipino contract workers on a government to government basis and to ensure compliance therewith."150 Article 19 establishes an Office of Emigrant Affairs within DOLE to "maintain close ties with Filipino migrant communities and promote their welfare." ${ }^{151}$ Finally, Article 22 makes remittance of a portion of foreign exchange earnings mandatory for all Filipinos working abroad. ${ }^{152}$

Book V of POEA's New Rules and Regulations Governing Overseas Employment lays out a standard format and establishes minimum requirements for contracts, including:

guaranteed wages for regular working hours, as well as overtime pay; free transportation from point of hire to site of employment and return; free emergency medical and dental treatment and facilities; termination only for just causes; workmen's compensation benefits and war hazard protection; repatriation of remains and properties in case of death; remittance of salaries, allowances or allotments to beneficiaries; adequate board and lodging facilities; and a grievance machinery for workers. ${ }^{153}$

On February 17, 1989, President Corazon Aquino signed Executive Order No. 348, which adopted and implemented the Philippine Development Plan for Women ("The Plan") over the next four years. The Plan requires that "legal and other forms of emergency and support services shall be fully extended to overseas workers who encounter problems in their countries of employment." 154 The Plan also calls for strengthening of the linkages between the government and private initiatives, including development of better strategies and an effective collaborative mechanism. Furthermore, the Plan gives more support for non-governmental organizations that provide information exchange services to workers abroad. ${ }^{155}$ An effective grievance mechanism or emergency assistance system, located in both the Philippines and host countries, would represent an important step forward. However, the most important requirement under the Plan is the ratifica-

149. LABOR CODE, supra note 9, at 73-74 (emphasis added). Article 12(g) requires the State to "insure careful selection of Filipino workers for overseas employment in order to protect the good name of the Philippines abroad." Id.

150. Id. at 77 (Art. 17(2)).

151. Id. at 77-78.

152. Id.

153. Id. at 605-06.

154. Development Plan for Women, supra note 57, at 128 (emphasis added).

155. Id. 
tion of International Labour Organization (ILO) agreements pertinent to migrant workers. ${ }^{156}$

\section{Governmental Assistance}

Another agency pushing for the protection of worker interests is the Overseas Workers' Welfare Administration (OWWA), which also was created in 1982.157 OWWA is an independent financial agency responsible for developing and managing an overseas workers' welfare fund. It provides workers with assistance on legal problems, job placement, insurance coverage, and jobs skills training. ${ }^{158}$ One program sponsored by OWWA since its inception is the Hatid-Saya, a regular musical outreach program targeted for jobsites in selected areas. ${ }^{159}$ A large portion of OWWA funds is also spent on the repatriation of distressed workers-in 1992 alone OWWA repatriated more than 3000 distressed workers. ${ }^{160}$ To reach out to more people, OWWA has put up regional offices throughout the Philippines, and established welfare centers abroad. ${ }^{161}$ The welfare centers provide services such as crisis intervention, counselling, conciliation, temporary OCW shelter, and repatriation, among others. ${ }^{162}$

OWWA's most successful impact on worker welfare appears to stem from its livelihood training and assistance programs. OWWA continuously conducts seminars and workshops on various livelihood projects. Participants who pass the courses are immediately entitled to apply for loans to start projects of their own. ${ }^{163}$ For example, a former domestic worker in Hong Kong, who regularly remitted her salary to support a strawberry farm run by her husband, obtained a loan through the Integrated Return Program for OCWs (IRPO) to supplement their investment. ${ }^{164}$ Also, a former textile worker in $\mathrm{Ku}$ wait started a production and training center with a loan from IRPO, and her new business trains potential overseas workers and produces

156. Id. See, e.g., infra text accompanying notes 213-14.

157. See supra text accompanying note 35 (discussing Phil. Executive Order No. 797).

158. Id. at 177-78. Alegado also cites 1977 Letter of Instruction No. 537 (presumably establishing the fund in response to media reports concerning maltreatment and abuse of Filipino workers and complaints from their families). Subsequent Presidential Decrees 1694 and 1809 institutionalized the fund and the agency. Id.

159. Leonardo Belen, OWWa to Work for More OCW's Benefits, Phil. Panorama, May 2, 1993 , at 5 .

160. Id.

161. Id. In 1991, the regional offices served some 57,209 client requests. The welfare centers are located in Hong Kong, Singapore, Tokyo, Brunei, Rome, Milan, Athens, Madrid, Riyadh, Jeddah, Oman, Kuwait, Abu Dhabi, Dubai, Bahrain and Tripoli.

162. Id. From 1988-91, the welfare officers assisted 494,487 OCWs in various ways, including direct assistance during the Gulf War.

163. Id.

164. Id. 
clothes for export to the Middle East. ${ }^{165}$ In 1989, OWWA set aside 26.1 million pesos for its lending program. By 1991, it had already funded 1632 projects, involving 1409 individuals, through 26.9 million pesos in loan grants, while employing 3604 in new jobs. ${ }^{166}$ Through its family assistance program, which loans cash to families of overseas contract workers, OWWA made loans to 5926 beneficiaries between 1987 and $1991 .{ }^{167}$

A newly-added service, which OWWA will soon be implementing in all its regional offices, involves the establishment of commissarytype stores to provide goods at cheaper prices for OCW dependents. ${ }^{168}$ OWWA Administrator David Corpin, who feels that OWWA is still not providing enough benefits for returning overseas contract workers, is now working on the development of an Overseas Workers' Cooperative Bank, in which each overseas contract worker would possess a shareholder interest. ${ }^{169}$ The proposed bank also may help solve the remittance problems associated with overseas workers-it is estimated that an unrecorded seven billion pesos "slip" into the Philippines annually, outside of the remittance process. ${ }^{170}$ Theoretically, the Overseas Workers' Cooperative Bank would draw this money into the open, and make it more productive by benefitting the OCWs and the economy as a whole. Administrator Corpin also reports that OWWA is intensifying its participation in the Pag-ibig fund for housing loans. ${ }^{171}$

\section{B. Intergovernmental Controls and Ambassadorial Advocates}

\section{Bilateral Arrangements}

The prospects for protection of overseas workers while abroad are dim, given the paucity of bilateral agreements (BLAs) between the Philippines and labor-importing countries. This problem is compounded by the inadequacy of mechanisms for monitoring compliance with the rules and regulations that are in place. ${ }^{172}$ Under the Philippine Development Plan for Women, the use of BLAs is strongly encouraged. Specifically, Philippine negotiators must seek to incorporate the following elements in a "harmonious arrangement" with importing countries:

165. Id.

166. Id.

167. Id.

168. Id.

169. Id.

170. Id.

171. Id.

172. Development Plan for Women, supra note 57, at 123. 
(1) adoption of standard employment contracts and wages;

(2) adoption of procedures for resolving labor cases;

(3) coverage of labor laws and/or social security laws for Filipino overseas workers; and

(4) imposition of visa requirements for identified countries with a history of exploitative conditions. ${ }^{173}$

As of 1988, the Philippines had forged BLAs with only three countries-Qatar, Jordan, and Iraq. ${ }^{174}$ Prior to its reorganization into a Department, the Ministry of Labor and Employment also reported that on December 18,1986, its Bureau of Working Conditions forged an agreement with Japan. ${ }^{175}$

The presence of a BLA with Japan did not automatically translate into worker protection. "Although the Philippine government has set up a shelter in the Setagaya district of Tokyo for Filipinos facing forced prostitution and exploitative work conditions," until recently the country had not publicly protested the abuse of its workers. ${ }^{176}$ Most likely, the Philippines was initially deterred by its dependence on Japan's economy and governmental aid, but its reliance on remittances from its nationals working abroad to obtain much-needed foreign exchange also played a role. ${ }^{177}$ In March 1992, however, then acting Labor Secretary Nieves Confesor stated that the law barring entertainers below twenty-three years of age from working in Japan would remain in effect until Philippine and Japanese authorities negotiated measures to protect young women from exploitation. ${ }^{178}$

The recent activism of the Philippine government may reflect a mandate adopted by the Philippine Development Plan for Women, ${ }^{179}$ which unequivocally requires that "measures shall be adopted to raise women's consciousness to improve their self-perception, increase their self-respect and self-confidence, and develop their full potential to significantly contribute to national development." ${ }^{180}$ More precisely,

173. Id. at 128 .

174. Id. at 124. But see supra note 34 (citing Alegado for BLAs with several other countries).

175. Ministry of Lab. \& EMpl., 1986 Annual Report 20. This agreement related primarily to social security benefits; however, it is clear that the working conditions of Filipinos in Japan are not adequately protected.

176. Selby, supra note 119 , at 362 .

177. Id. (referring to an interview with Wun'gaeo Surichai, Thai Professor of the Sociology of Development at Hosei University, Tokyo, Japan, on December 14, 1988).

178. Overseas Ban Protested, Honolulu Star-Bulletin, Mar. 21, 1992, at C1.

179. See supra text accompanying notes 57-58.

180. Aura Ancheta Sabilano, The Status of Women Workers, 8 PHIL. J. Indus. Rel. 63 (1986). See also LABOR CODE, supra note 9, at 243-64 (Title III: Working Conditions for Special Groups of Employees); Purificacion v. Quisumbing, The Position of Women Under Labor Laws of ASEAN, 9 PHIL. J. Indus. Rel. 138 (1987). The provisions of the Labor Code were given teeth in Republic Act No. 6725 (Strengthening Prohibition on Discrimination Against Women), which was approved on May 12, 1989. RAmos, supra note 12, at 69 n.115. 
"protection shall be accorded to specific groups which include women, youth, rural workers, and overseas workers." 181 The Plan also calls for a policy of "gradual but sustained phasing-out of overseas employment" for domestic workers and entertainers. ${ }^{182}$ In its place, the government's "top priority" shall be to advance a radically new development strategy calling for the creation of "domestic economic opportunities for women [that will] . . . circumvent the massive outflow of female skilled workers." 183

\section{Consulates}

Article 21 of the Philippine Labor Code provides important protection for overseas workers by establishing duties of labor attachés who are assigned to foreign embassies. Among their other responsibilities, they are required to:

(a) provide assistance to all Filipino workers within their jurisdiction on all matters arising out of employment;

(b) insure that Filipino workers are not exploited or discriminated against; and

(c) verify and certify, as a prerequisite to authentication, that the terms and conditions of employment contracts are in accordance with the Labor Code and rules and regulations of the Philippine Overseas Employment Administration. ${ }^{184}$

Access to embassies can be difficult, especially because the travel distance is an impediment for overseas workers, and employers often will withhold their passports. Nonetheless, action is possible. In Novem-

181. Sabilano, supra note 180 , at 63 (emphasis added).

182. Development Plan for Women, supra note 57, at 126.

183. Id. at 127. The Plan calls for this goal to be obtained through: (1) diversified skills training and development, to open alternative employment opportunities; (2) pre-employment programs, strengthened through information dissemination and a holistic approach towards the control and eradication of illegal recruitment; (3) prohibitive penalties for illegal recruiters; (4) a special court; (5) strict monitoring; (6) effective enforcement and penalties for violators; and (7) feedback mechanisms. Id.

The Plan also includes a Legislative Agenda for Overseas Women Workers:

(1) enacting a law making illegal recruitment a crime and imposing prohibitive penalties for illegal recruitment;

(2) establishing stricter documentary requirements for tourists in areas where exploitation is prevalent;

(3) establishing strict enforcement and implementation of registration requirements upon arrival in a foreign country;

(4) establishing strict guidelines and supervision of artist groups;

(5) forging BLAs with host countries;

(6) ratifying/adopting ILO Conventions pertinent to migrant workers;

(7) applying international laws in the adjudication of cases in host countries;

(8) pursuing only discriminate deployment of Filipinos, based on a review of the work and living conditions in the host country;

(9) establishing special courts to prosecute illegal recruitment cases; and

(10) establishing guidelines on rural recruitment (i.e., "training").

Id. at 133-34.

184. Id. at 79 . 
ber 1991, the Philippine embassy in Islamabad urged a ban on sending housemaids to Pakistan and "rigidly Islamic countries" following complaints of maltreatment by their employers. ${ }^{185}$

\section{Host Country Protections}

Japan's extensive network of laws protecting laborers from exploitation "technically should apply to foreign workers as well as Japanese nationals." ${ }^{86}$ In fact, various communiqués from the Japanese Ministry of Labor state that "the Employment Security, Temporary Workers, and Labor Standards Laws apply equally to all so long as they are employed in Japan, without regard to whether they are Japanese or not, and further without regard to whether they are illegally working or not." 187 They also note that "no employer shall discriminate against or for any worker by reason of nationality, creed or social status in wages, working hours and other working conditions."188 Although originally intended to protect Koreans and Taiwanese from discrimination, nothing in the law suggests that these should not apply equally to workers from other countries. ${ }^{189}$

Japanese law does not authorize work permits for unskilled laborers. ${ }^{190}$ Nonetheless, many hopeful Filipino workers enter the country illegally with hopes of better living conditions, despite the fact that their lack of legal status effectively precludes enforcement of their rights. ${ }^{191}$ Although the Ministry asserts that deported aliens can pursue any civil or criminal claims that they may have against their former employers by hiring a lawyer from their home country, it has been said that this view "approaches flippancy." 192 As a result, the enforcement of labor and prostitution prevention laws will remain impossible so long as the deportation provisions of the immigration law take precedence. ${ }^{193}$ Meanwhile, Japanese bar owners acknowledge

185. Clift, supra note 3.

186. Selby, supra note 119, at 344 (quoting Hayashi, Nihon Niokeru Gaikokujin Tanjun Rodosha [Simple Laborers in Japan], HorrTsU JiHU 33, 38 (1987)).

187. Id. at 345 (quoting NiHON BeNGoshi ReNOo KaI, Jinken no KoKusatTeKi Hosho [International Protection of Human Rights, Basic Report of the First Department ENFORCEMENT COMMITTEe] 237 (1988) (emphasis added)).

188. Id. (quoting Rodo Kijun Ho, No. 49, art. 3 (1947)).

189. Id. (referring to Nishitani, Gaikokujin Rodosha to Rodo Ho [Foreign Laborers and the Labor Laws], 42 Hogaku Seminar 128, 130 (1988)). See generally Haruo Shimada, Japan's "Guest Workers": Issues and Public Policies (1993).

190. Id. at 341 .

191. Id. at 342.

192. Id. at 364 (quoting an interview with attorney Mizuho Fukushima in Tokyo, Japan, on December 6,1988 ). Fukushima successfully conducted a case involving a compensation claim for medical complications for a woman who was deported to the Philippines. However, she can recount many more cases that could not be brought because of the victim's deportation. Id.

193. Id. at 363. 
the pervasiveness of abuse, and note that "many of us take advantage of the women, in one way or another. But they keep coming back because of the pay."194

\section{Non-Governmental Support}

When governmental assistance does not provide adequate protection, overseas workers have several other options available.

\section{Religious Groups}

The Catholic Church of the Philippines has established two shelters in Hong Kong for homeless women, providing assistance through social workers who negotiate with the Labor Department and employers. ${ }^{195}$ Sister M. Tarsila Abano, Director of the Center for Overseas Workers of the Good Shepherd Convent, has called for a thorough review of the Philippine overseas labor program. ${ }^{196}$ Other religious organizations have put pressure on local governments to improve labor laws in the host country.

The church-based Mission for Filipino Migrant Workers criticized a 1987 legislative measure in Hong Kong that created "a system where abuses could be made to flourish because the victims [would] not be able to remain in Hong Kong."197 That particular legislation: (1) prohibited maids from changing employers within the first two years of an employment contract; (2) forced Filipinas to return to the Philippines to submit to new employment contracts; and (3) prohibited maids from staying in Hong Kong for more than two weeks after their contract had terminated. ${ }^{198}$ Furthermore, the contract system set up by the Hong Kong government was biased in favor of employers. For example, weekly hours of work were not specified, domestic work was not defined, only one-month notice was required for legal termination, and maids were required to obtain a release letter to change employers (aside from being required to return to the Philippines to process new employment forms). ${ }^{199}$ The Mission organized a huge protest of these regulations at the Catholic Center in Hong Kong on

194. Eugene Moosa, Manila Minister to Probe Death of Filipina Dancer in Japan, Reuter Libr. ReP., Oct. 16, 1991.

195. Ludmilla Kwitko, Survival Strategies for Filipina Domestic Workers in Hong Kong 13 (Apr. 22, 1992) (unpublished paper presented at Chinese Studies Colloquium Series, University of Hawai'i). 9.

196. Edgar P. del Val, Help for Women Overseas Workers, Phil. Panorama, May 2, 1993, at

197. Id. at 15 (quoting the South China Morning Post, Apr. 20, 1987).

198. Kwitko, supra note 195 , at 14.

199. Id. 
May 10, 1987..$^{200}$ As noted above, ${ }^{201}$ although the Philippines subsequently banned all forms of overseas domestic employment for its citizens, less than two months later the ban was lifted in Hong Kong and Canada without any sign that labor agreements had been negotiated. ${ }^{202}$

\section{Individual Action}

In addition to formal governmental action, diplomatic posturing, and support from religious organizations, Filipinas have demonstrated the ability to react on their own behalf. Six Filipina computer operators established the first foreign labor union in Japan to improve not only their own labor standards, but also the conditions of all Filipinas working in Japan. ${ }^{203}$ For an example of the union's success, one needs only look at Jayne Moreno, a co-founder of the union. Jayne was issued two versions of an employment contract by a Japanese employer. Although POEA approved Jayne to work in Japan only on the basis of the second contract, her employer applied the initial contract once she arrived in Japan. ${ }^{204}$ After the union objected, the president of the company eventually accepted a statement of demands from the Filipina workers, and pledged to enter into collective bargaining and rectify contractual provisions that violated any law. ${ }^{205}$

\section{Non-Governmental Organizations}

Overseas Filipino workers also can draw support from groups in the Philippines such as KAIBIGAN (Friends of Migrant Workers), $K A K K A M P I$ (Congress of Overseas Filipino Workers and their Families), ${ }^{206}$ and the Trade Union Congress of the Philippines. ${ }^{207}$ Ruby Palma Beltran, co-founder of the Women in Development Foundation, and approximately a dozen other leaders formed a coalition of non-governmental organizations (NGOs), religious groups, and research institutions for Filipina migrant workers. ${ }^{208}$ The NGO coalition recently submitted a resolution to President Fidel Ramos

200. Id. at 16 .

201. See supra text accompanying note 133 .

202. Kwitko, supra note 195, at 17.

203. Filipino Workers Set Up Labor Union in Japan, Kyodo News Service, Feb. 28, 1990. The union belongs to the National Union of General Workers. Id.

204. The first contract was not accepted by the Philippine Embassy in Japan because it violated the Minimum Wages regulation of Japan's Labor Standard Law. Deductions for housing and other necessary costs, which the company exercised under the first contract, are permitted only if provided for under a contract with a labor union. Id.

205. Id.

206. Alegado, supra note 8, at 184.

207. E. P. del Val, supra note 196, at 9.

208. Id. 
requesting the establishment of an advisory council under the Office of the President specializing in problems of women migrant workers. $^{209}$ The NGOs also asked for an "effective, responsible, and workable" redress and grievance mechanism for women migrant workers suffering abuse. ${ }^{210}$

NGOs in host countries are another useful source of support. For example, in Japan, the Civic Group to Consider the Philippines and Japan has provided important support since 1983. ${ }^{211}$ Also, since 1987 Carabao no Kai has sought to foster friendship and solidarity between Japanese and Asian migrant workers, particularly Filipinos. This group also assists migrant workers with labor problems as well as standard of living concerns such as housing, language training, and health care. ${ }^{212}$

On the international level, recent completion of the "International Convention on the Protection of the Rights of All Migrant Workers and Members of Their Families" 213 provides an important opportunity to improve the conditions of employment for many overseas workers. The Convention extends the protection of fundamental human rights to all migrant workers, whether they are documented or undocumented, and, to a lesser extent, members of their families. ${ }^{214}$ By recognizing overseas workers and their families as social beings rather than mere laborers or economic entities, the Convention seeks to establish uniformly acknowledged minimum standards for overseas employment. ${ }^{215}$ The Convention also permits individuals, not only their governments, to file claims alleging violations of their rights to supervising committees. Furthermore, signatory states are obliged to submit reports on any legislative, judicial, administrative, or other governmental measures taken to give effect to the Convention. ${ }^{216}$ The next important hurdle is to obtain consent from countries involved in

209. Id.

210. Id.

211. Selby, supra note 119, at 354-55. See also Japan-Filipino Children in P.I. Gain Backers, Honolulu Star-Bulletin, Sept. 26, 1994, at A8 ("Batis, a group helping Filipino workers abroad, said it will host a Japanese-Filipino legislators conference in November to discuss labor conditions of Filipino workers in Japan, intermarriages and Japanese-Filipino children.").

212. Id.

213. For a reprint of the Convention, see 25 INT'L Migration REv. 873 (1991).

214. Shirley Hune, Migrant Women in the Context of the International Convention on the Protection of the Rights of All Migrant Workers and Members of Their Families, 25 INT'L MIGRA. TION REV. 800, 807 (1991).

215. Id. at 808. Although the Convention significantly advances the interests of women, no provisions address the exploitation of women through prostitution and sexual entertainment, or rectifying the sexual abuse, violence, and harassment of women. Therefore, migrant women workers are still at risk if the general protections provided are narrowly interpreted. Id. at 810 .

216. Jan Niessen \& Patrick A. Taran, Using the New Migrant Workers' Rights Convention, 25 INT'l Migration Rev. 859, 862-63 (1991). 
the labor trade to be bound by the provisions of the Convention. Currently, neither the Philippines nor any country with a high number of Filipino workers are signatories to ILO Resolutions and Conventions that recognize workers' rights. ${ }^{217}$

\section{Evaluating the Existing Philippine Overseas EMPLOYMENT Policy}

Ironically, the structural limitations that initially prompted the Philippine government to adopt its current labor export policy in fact have contributed to the persistent abuse of Philippine workers overseas. Since remittances from these workers generate in excess of one billion dollars of revenue per year, they are extremely important to the Philippine economy. ${ }^{218}$ At least one commentator has suggested that, but for these remittances, the Philippine economy would have collapsed during the critical months of the Gulf War crisis. ${ }^{219}$ In addition to shoring up the country's foreign exchange reserves, overseas employment also helps to give Filipino workers a more global perspective-which is especially important at a time when nations are becoming more interdependent. ${ }^{220}$

Until opportunities in the Philippines are improved, Filipinos will continue to risk the abuses associated with overseas labor in search of a better life for themselves and their families. Critics of the government's efforts contend that existing regulations are doing more harm than good. For example, Napoleon Rama points to workers' ability to accept only 5000 out of 65,000 jobs made available to Filipinos by Taiwan, where the most industrial city is only twenty minutes away by plane. ${ }^{221}$ Pointing to the insuperable bureaucratic hurdles established by the government, Rama wrote:

It is time now to spare the poor job applicants from the old motherhen concern of the Department of Labor people ...; ; [i]t's more important to liberate him from too much government regulations that in the end deprive him of a job and, hence, make him very vulnerable to different kinds of hazards in life. ${ }^{222}$

Other commentators disagree with the government's decision to make what was initially designed as a temporary remedial action a

217. Alegado, supra note 8 , at $317-18$.

218. See Asia \& PACIFIC Rev. 1993/94, supra note 6, at 216 (estimating approximately about $\$ 1.5$ billion per year); E. P. del Val, supra note 196, at 9 (estimating $\$ 1.18$ billion per year); Reyes, supra note 10, at 30 (estimating greater than one billion dollars per year).

219. Reyes, supra note 10 , at 30 .

220. Id.

221. Napoleon G. Rama, Whatever Happened To The 65,000 Taiwan Jobs for R.P.?, PHIL.

Panorama, Apr. 4, 1993, at 3.

222. Id. at 34 . 
major component of Philippine economic development. At least one non-governmental organization wants the industry phased out. ${ }^{223}$ However, this approach does not appear realistic when considering the current state of the Philippine economy. ${ }^{224}$ When identifying the main policy challenge facing the Ramos Administration, former Labor Secretary Blas Ople called upon the government to reverse its labor export policy by observing,

The Philippine strategy ... has been to deter if not reject foreign investments and technology through policies that emphasize domestic protection. By implication, this strategy calls for sending our labor surpluses abroad, to those countries where more open policies have succeeded in mopping up labor surpluses and creating a labor shortage. 225

Academic experts at a seminar organized in 1992 by the ILO and United Nations University in Tokyo suggested that by the year 2000 most of the countries in East Asia, with the exception of the Philippines, will have solved their problems of chronic mass unemployment. ${ }^{226}$ These countries will soon experience labor shortages, and will be compelled to review their policies against admitting foreign workers. ${ }^{227}$ Ople reports,

Following in Japan's wake, the NICs such as South Korea, Taiwan, Hong Kong and Singapore, are experiencing acute manpower shortages .... Malaysia, Thailand and Indonesia are still labor exporters like the Philippines, but their phenomenal economic growth rates are rapidly changing the structures of their labor markets, away from surpluses to relative scarcity. Their governments have opted to bring in the investments and technology that will create remunerative jobs at home. ${ }^{228}$

Under the Philippine government's traditional labor policy, on the other hand, Filipinos will continue to serve simply as a "labor reserve" for the rest of the world. ${ }^{229}$ In effect, maintaining the status quo means "Philippine aid to the developed and newly industrializing countries for their progress and their development." 230

223. E. P. del Val, supra note 196 , at 9 (citing views of the NGO KAIBIGAN, which wants the phaseout to be pursued gradually over a fifteen-year period).

224. Id. A United Nations Development Program report released in June 1992, entitled Transforming the Philippine Economy, stated that "the Philippine economy as currently constituted cannot on a sustained basis generate economic development .... The problem of poverty is not the lack of jobs so much as the lack of jobs that pay good wages." Id.

225. Blas F. Ople, The Last Labor Exporting Country, Phil. Panorama, Nov. 22, 1992, at $44,45$.

226. Id. at 44.

227. Id.

228. Id. at 45 .

229. Alegado, supra note 8 , at 334 .

230. Id. (emphasis added). 
Under President Ramos' leadership, a political consensus appears to be emerging that favors moving towards a more liberal economy, reducing inflation, and bringing in more foreign investment. ${ }^{231}$ Labor Secretary Nieves Confesor has advised, however, that the overseas markets should continue to be tapped as a viable employment option. She "bristles at the idea that the economy must wait for investors to create new jobs, reduce unemployment, and increase the economy's productive capacity."232 According to Confesor, the government's future overseas employment policy will revolve around two strategies:

First, from a geographical perspective, export of labor shall be less Middle Eastern, more Western, more European, and more Asian. And second, from an occupational perspective, we will continue to export our fair share of blue collar workers and seamen, but ideally, the export of labor shall focus on the highly-skilled, the technical, the managerial and the professional, and at the same time less on domestic services and entertainment. ${ }^{233}$

\section{Conclusions}

Laws, rules, and regulations already instituted in the Philippines provide many of the necessary measures for protecting migrant workers, both pre-departure and post-arrival. Since public attention has focused on the abuse of overseas workers in recent years, the Philippine government has shown a willingness to take drastic action to "protect" its nationals-even to the extent of banning deployment. There is no guarantee, however, that this support will continue. History indicates that aggressive responses like these are typically followed either by premature capitulation or forfeiture of the labor market to competing countries. Meanwhile the initial advantages of the national labor export policy continue to deteriorate: (1) the occupational structure has shifted toward services (primarily domestic help); (2) an overall decline in benefits is apparent; and (3) the amount of illegal and undocumented workers is rising. This latter development has particularly harmful effects, since it increases the likelihood of abuse, while decreasing the anticipated reciprocal benefits to the exporting country.

Some labor importing nations also have laws that could be used to deter the abuse of both legal and undocumented contract workers in their countries. The willingness and capability of labor importing and exporting countries to enforce these laws, however, is another

231. See Asia \& Pacific Rev. 1993/94, supra note 6, at 215.

232. Reyes, supra note 10 , at 30 .

233. Id. at $30-31$ (emphasis added). 
matter entirely. In times of economic hardship, basic rights and rational policy are often ignored in favor of easy "solutions." Until minimum standards (such as those espoused in the Migrant Workers' Convention) are recognized by the international community, the abuse of overseas workers will continue unchecked-whether directed at current laborers, or at a new "crop" from another country.

If conditions are to improve, other governments must recognize their own responsibilities in this matter. They must support initial steps like the Migrant Workers' Convention, as well as aid to developing nations. Feelings of hope bolstered by the urgency that surrounded development of the Migrant Workers Convention have been replaced, however, by decreased international sympathy for the conditions of overseas laborers. ${ }^{234}$

[I]n the eyes of the public, migrants are increasingly seen as people who are causing problems instead of as people who contribute economically and culturally to the receiving societies. In times of economic restructuring or stagnation, tensions between nationals and migrant workers exacerbate, and this often leads to discrimination and racism. ${ }^{235}$

This change in circumstances was caused by a combination of events: (1) the end of the Cold War; (2) dramatic border changes in Eastern and Western Europe; (3) the uncertain global economy; (4) the continuing disparity of poverty and wealth throughout the world; and (5) swelling migrant populations of different racial and cultural backgrounds in receiving countries. ${ }^{236}$

These realities make Ruth Mabanglo's poem ${ }^{237}$ even more poignant. Individual communications like Pinay's letter play an important role by informing Filipinas (and other readers) of the substantial difficulties and problems associated with overseas employment. The message may not reach every potential migrant, but others will begin to understand that injustices that occur overseas are perpetuated through efforts to circumvent the law and their willingness to expose themselves to unfavorable risks. Hopefully, subsequent reevaluation will lead these determined souls to focus their energies on seeking necessary changes at home and in the international community. Since this goal probably cannot be accomplished alone, those of us living under more secure circumstances must assist. A motivated interna-

234. Hune, supra note 214 , at 814 .

235. Niessen \& Taran, supra note 216 , at 859-60.

236. Hune, supra note 214 , at 814 .

237. See supra text accompanying notes 1-2. See also Chris DeStoop, They ARe So Sweet, SIR (1994) (quoting a hotel manager as saying "[Filipinas] are our best export product."); Migrante (Kanlungan Center for Migrant Workers 1994) (documentary film about domestic helpers in Hong Kong). 
tional community can achieve significant results by applying pressure on both labor exporting and importing nations. 